\title{
MERCADOS ITINERANTES. ESTUDIO COMPARATIVO DE DOS MERCADOS EN MÉXICO
}

\author{
STREET MARKETS. COMPARATIVE STUDY \\ OF TWO MARKETS IN MEXICO
}

\author{
Felipe González Ortiz* \\ Sergio Vega Bolaños ${ }^{* *}$
}

\section{RESUMEN}

En este trabajo se realiza una comparación entre dos mercados itinerantes del metropolitano Valle de Toluca, México. Muestra el origen de los productos que se intercambian en cada uno de ellos y las maneras de articulación de las economías urbano-populares y campesinas e indígenas al mercado global, a través de este tipo de mercados. Se parte del reconocimiento que este tipo de mercados (los itinerantes) conforman un segmento de demanda $y$ oferta, por el que compiten con otras modalidades de comercio (mercados fijos, supermercados y mercados de élite), lo que ha dado entrada a un proceso de marginación de esta modalidad, ilustrada en la comparación de los mercados tianguis (para usar la expresión prehispánica) de Toluca y de Ixtlahuaca.

PALABRAS CLAVE: MÉXICO * MERCADOS ITINERANTES * ESTUDIOS COMPARATIVOS * COMERCIO * CULTURA

\section{ABSTRACT}

This paper aim is to make a comparison between two nomadic markets of the metropolitan area of Toluca, México. It shows the origin of each one of the products that are exchanged in these markets and the forms of articulation of urban and country or indigenous economies, contrasting them with global markets. This work recognizes the importance of street markets in the supply and demand economical cycle, which tendency, is to consider only supermarkets and elite markets into the economical competition rates of a city. Street markets are commonly left behind, but for societies like Toluca, they represent a common place of recognition and gathering processes. Tianguis (as in the pre-Hispanic word) from Toluca and Ixtlahuaca are been analyzed in this article.

KEYWORDS: MEXICO * ITINERANT MARKETS * COMPARATIVE STUDIES * COMMERCE * CULTURE

\footnotetext{
* $\quad$ Facultad de Ciencias Políticas y Sociales de la Universidad Autónoma del Estado de México. felsus1@yahoo.es

** Facultad de Ciencias Políticas y Sociales de la Universidad Autónoma del Estado de México. sergio.vegab@yahoo.com.mx
} 


\section{INTRODUCCIÓN}

El presente artículo compara dos mercados itinerantes del valle de Toluca, en el centro de México. Dicha comparación se realizó con trabajo de campo etnográfico durante los meses de junio a diciembre del año 2014. Se seleccionó estos dos mercados itinerantes en la medida que representan distintas formas de articular las economías campesinas indígenas y urbano-populares con la economía global, lo cual permite la comparación e ilustra la hipótesis del trabajo.

Se trata de los mercados itinerantes, de un día a la semana, de Ixtlahuaca y de Toluca. Los dos mercados se instalan en distintos días de la semana en un espacio singular para ofertar bienes $y$ atienden a una demanda de escasos recursos que llegan de comunidades indígenas y colonias populares que se encuentran en los alrededores de dichos mercados. En este sentido, estos mercados representan una forma de articulación de las economías urbano-populares, campesinas e indígenas al mercado global, conformando un segmento de oferta y demanda propio de estos sectores sociales.

Siguiendo esta hipótesis, se configuran regiones de comercio en las que se articulan estas economías populares al mercado global a través de la red de mercados itinerantes. En esta dinámica, los mercados itinerantes constituyen espacios comerciales de integración regional mediante el intercambio de bienes entre sectores de bajos recursos económicos.

De acuerdo con Castillo, se entiende el mercado como una institución económica donde las sociedades confluyen en función del consumo y del intercambio, advierte además, que los mercados son una construcción histórica donde subyace la distribución de bienes $y$ el encuentro entre productores $y$ consumidores (1995, 11). Por lo cual surge la interrogante de si los mercados itinerantes, llamados tianguis ${ }^{1}$ en la tradición oral mexicana, constituyen escenarios articuladores de las economías familiares populares, campesinas e

1 La palabra tianguis es de origen náhuatl y significa mercado. indígenas, con el mercado global, representando aglutinadores regionales del intercambio de bienes. En esta pregunta se esboza la hipótesis de este trabajo.

En este contexto, es importante anotar que estos dos mercados se instalan (los lunes el de Ixtlahuaca y los viernes el de Toluca), en zonas de intensa urbanización metropolitana, recibiendo la influencia de las metrópolis del valle de Toluca y la del valle de México, pues estas se convierten en proveedoras de buena parte de las mercancías que se ofertan en ellos. La imagen 1 muestra la ubicación de estos dos mercados en el marco de la megalópolis del centro del país ${ }^{2}$, caracterizada por la presencia de grandes centros metropolitanos y comunidades de vocación agrícola en sus alrededores.

2 Partiendo de una definición funcional y operativa, se entiende que una metrópolis se define en el momento que el crecimiento de la ciudad incorpora otra unidad administrativa distinta a la de su origen, mientras que la megalópolis refiere a una articulación estrecha entre varias metrópolis (Garza 2000). En este sentido, no hay posibilidad de que la megalópolis escape de la cualidad difusa (Nivón 2003), pues incorpora en su dinámica propia a una región que se configura por la articulación de varias metrópolis y zonas rurales de vocación agrícola y ganadera incorporadas en una misma dinámica de expansión. 


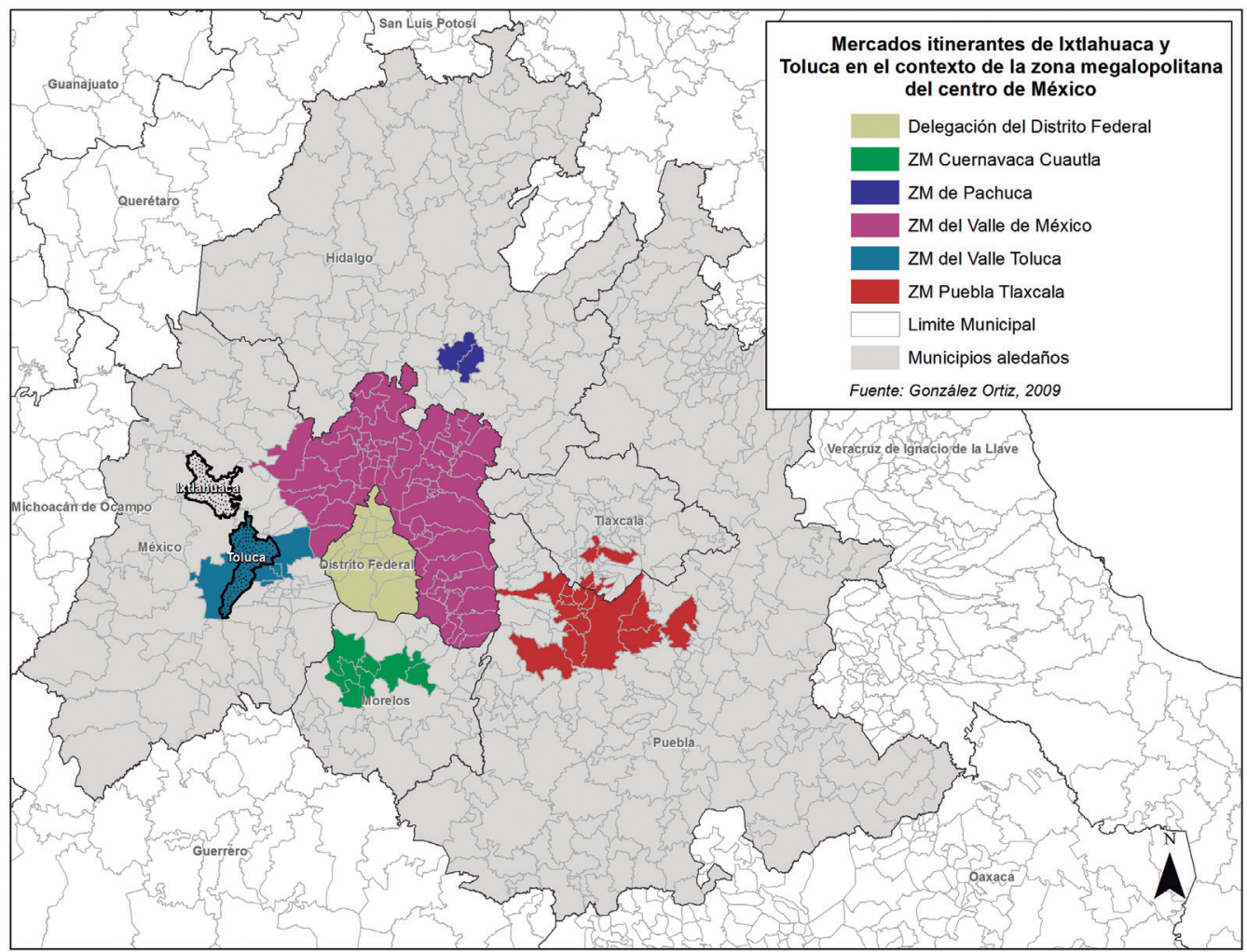

IMAGEN 1

MERCADOS ITINERANTES DE IXTLAHUACA Y TOLUCA EN EL CONTEXTO DE LA ZONA MEGALOPOLITANA DEL CENTRO DE MÉXICO

Fuente: González, 2009.

La articulación entre mercados itinerantes $y$ las regiones se construye con base en las interacciones comerciales, pero es un hecho que este tipo de mercadeo aglutina a un segmento de la sociedad, el más pobre, que proviene de los pueblos, comunidades indígenas y las colonias urbano-populares ${ }^{3}$.

A lo largo del trabajo se verá que la existencia de ciertos bienes como son las aves de corral, las raíces, frutas o verduras de la recolección y los frutos del huerto, pueden caracterizar la existencia de productos campesino indígenas que a su vez configuran modos de

3 Por colonia urbano-popular se entiende a aquellos asentamientos metropolitanos con baja consolidación urbanística, con casas de materiales baratos $y$ construcciones inacabadas $y$ en muchos casos sin tener en regla la propiedad del suelo (Lindón 1999). vida en la medida que se destinan al fondo ceremonial de sus comunidades. De esta manera, el comercio o mercadeo en mercados itinerantes conecta al segmento más pobre de la sociedad con el mercado global, pero a la vez, la práctica comercial se redescubre como un espacio de comunicación y socialización donde se construyen valores $y$ tradiciones que identifican a una región. Por ejemplo, las relaciones de parentesco entre los puestos de oferentes, se pueden encontrar, en los dos casos, una genealogía que articula a las generaciones de hijos con la diversificación de bienes ofertados, es decir, existe una tradición a seguir generacionalmente el oficio del comercio pero diversificando la oferta, de tal suerte que el abuelo vende frutas; el hijo herramientas y los nietos dulces y galletas; de la misma forma puede encontrarse una diferenciación según el sexo, pues es frecuente que los artículos de fantasía sean vendidos por mujeres. 
Otro aspecto que es similar en los dos mercados es el aprendizaje de las maneras de vender que desarrollan los miembros de la familia, por ejemplo, los niños salen a vender de manera ambulante por los pasillos del mercado mientras sus padres o abuelos los esperan en el puesto, de esta manera se juega una especie de transmisión del conocimiento a las nuevas generaciones que terminan por configurar estilos de vida propios de estos sectores de oferentes. Los lazos de parentesco ritual como el compadrazgo son también una constante entre los oferentes. Este lazo se ha extendido incluso a la demanda, pues la regularidad del trato comercial no solo genera clientelas sino va más allá al insertarse en la lógica del compadrazgo, mediante el apadrinamiento de algún niño.

Este tipo de relaciones culturales son posibles por el hecho de pertenecer a un mismo sector social que comparte, en términos generales, mismos valores y misma cognición sobre el mundo que los rodea, de tal suerte que la dimensión regional y el status social confluyen para dar forma a esta actividad del comercio en los mercados itinerantes. Este hecho es fundamental resaltarlo en la medida que la forma empíricamente observable de las interacciones comerciales (los colores, regateos, gritos de oferentes, cuentas domésticas calculadas en efectivo, risas, competencias disfrazadas de alegría, comidas familiares sobre la banqueta, tragos de cerveza, de pulque o de alcohol, productos fiados, préstamos de dinero) mantienen un contenido simbólico y cognitivo de una densidad caracterizada por las mallas de solidaridad que se realizan entre los oferentes y los demandantes, que termina por contribuir a la subsistencia, componente de la grandeza solidaria de los sectores pobres ante el hecho de que en su cotidianidad siempre terminan asegurando, día tras día, el sustento para la subsistencia (Maffesoli 1991).

De esta forma, las interacciones comerciales cotidianas tienen el potencial de fortalecer las relaciones sociales entre los oferentes $y$ demandantes que conforman este sector social, con lo cual se potencia la mercancía fiada o regalada, pero también el trueque, sobre todo de aquellas unidades familiares que asisten al mercado con productos de la recolección o del huerto, tales como frutas, hongos o hierbas del monte.

Tanto el mercado de Ixtlahuaca como el de Toluca tienen orígenes antiguos. El nombre genérico con el que se les conoce a este tipo de mercadeo itinerante es con la palabra tianguis, proveniente de la lengua náhuatl, cuyo significado es junto al mercado (Villela 2013, 75), aunque en términos genéricos significa mercado. No obstante, tratarlo en su primera acepción genera la idea de una actividad instalada junto a otra modalidad de mercadeo fijo. Esta distinción conceptual coloca el tianguis como un tipo de mercadeo no fijo, sino itinerante, lo que a su vez representa una tentación permanente, para los funcionarios de gobierno y empresarios del comercio, que intentan desacreditarlo con denominaciones estigmatizantes al definirlo como comercio informal cercano o susceptible de volverse ilegal. Esta caracterización negativa se ilustra en el caso del mercado de Toluca, pues en la historiografía de sus dos reubicaciones siempre se acompañaron de estigmas que terminaron en justificaciones gubernamentales para la reubicación urbana.

En este trabajo se plantea la postura de que el tianguis no es comercio informal, sino se inserta en tipos de actividades económicas de larga duración histórica con articulaciones precisas en el mercado global, para seguir con la hipótesis planteada en este trabajo. Los orígenes de este tipo de mercadeo se encuentran en los tiempos prehispánicos. En este sentido, se define mercadeo como aquellas prácticas sociales de comercio que configuran demandas $y$ ofertas regionales segmentadas por criterios de clase social (status) y de pertenencia étnica y cultural. De esta manera, la práctica de mercadeo itinerante convive $y$ compite con otras formas de mercadeo tales como los mercados fijos, los supermercados y los establecimientos de mercado de elite ${ }^{4}$. En todos estos tipos de mercadeo existe la posibilidad de realizar el

4 Plazas comerciales donde se establecen comercios con firmas internacionales y transnacionales. Dichas plazas se caracterizan por resaltar el consumo de elite o clase en establecimientos cargados de seguridad y de mínima socialización. 
comercio informal, de ahí que identificar al comercio itinerante con el comercio informal no solo es una distinción injusta, en la medida que cualquier modalidad de mercadeo permite la informalidad, sino al significar solamente que se está preparando una política hacia los pobres, generalmente los usuarios del mercadeo informal, que terminará por excluirlos socialmente en pro de la llamada limpieza urbana.

La existencia de estas otras modalidades de mercadeo significa, desde la oferta, una competencia por la demanda, lo que hace que las definiciones cobren importancia en la medida que las desacreditaciones, los estigmas, los estereotipos, los reduccionismos y los falsos reconocimientos sean una forma ideológica de competir por la demanda regional y la totalidad de segmentos de demanda social. La veracidad de esta postura radica en el hecho de que en aquellos lugares en los que existe o existió un tianguis, se han instalado formas de mercadeo distintas, tales como el mercado fijo, propio de la Colonia y el supermercado, propio de los tiempos modernos ${ }^{5}$.

De esta manera, se puede realizar una "arqueología" de los mercados en función de capas temporales observables en la confluencia de las distintas modalidades de mercadeo. Estas no significan una apertura a la diversidad, sino una competencia por la demanda y la posibilidad de movilizar recursos políticos para la desacreditación de dicho segmento de demanda $y$ oferta.

En este sentido, la capa más antigua la representa el tianguis, cuyo origen se remonta a los tiempos prehispánicos ${ }^{6}$. En esos tiempos, la creación de los mercados fomentó el impulso del desarrollo demográfico, principalmente en

$5 \quad$ En el mercado de Santiago Tianguistenco incluso se ha instalado un centro comercial de elite que aglutina a tiendas de firmas internacionales $y$ construye el espacio para el goce del consumo.

El propio Bernal Díaz del Castillo anuncia que a su llegada al mercado de Tlatelulco "quedamos admirados de la multitud de gente y mercaderías que en ella había... Y los principales que iban con nosotros nos lo iban mostrando, cada género de mercaderías estaban por sí, y tenían situados y señalados sus asientos" (Díaz del Castillo 2012, 243). las ciudades, ya que permitía el crecimiento de los asentamientos o creaban nuevos centros urbanos.

En México, el mercado prehispánico era denominado Tianquixtli que designaba al mercado o plaza donde se realizaban los intercambios comerciales, los cuales contaban con una infraestructura amplia conformada por vías de comunicación y transporte, así como una serie de valores y tradiciones sobre cómo debía realizarse el intercambio denominado trueque 0 patlalli tlapatiotl (Alvear 2004, 90).

En este esquema de competencias por la demanda, según el enfoque del artículo sobre la segmentación social del mercado, Castillo menciona que en el proceso de intercambio en los tianguis se pueden reconocer tres grandes etapas:

Trueque, precedido o no de regalos mutuos.

Truque-moneda, etapa característica del comercio entre los aztecas de la época de la conquista y en la que se encuentran muchas comunidades indígenas de la actualidad.

- Economía monetaria, predominio del uso de papel moneda $(1995,14)$.

Castillo $(1995,34)$ observa que otras características comunes a los tianguis son la utilización de tiempos amplios (todo un día) para la transacción comercial; vigencia de productos culturales tradicionales tales como metates, hierbas, vestimenta, insectos y utensilios; paridad y equivalencia en los intercambios comerciales, ya sea en trueque o monetario; uso del regateo; extensa presencia de pregoneros; se realizan al aire libre; ocupan las calles o lugares completos de los pueblos y poseen un agrupamiento de oferentes según la naturaleza del producto que comercializan. Esta observación es interesante porque le asigna al tianguis una cualidad festiva en el sentido que todos participan de un escenario puesto un día a la semana para desplegar las estrategias de la venta y la compra; se trata de un día que rompe 
con la monotonía de la semana, un día especial para hacer las compras; en el mercado tianguis todos son merolicos; todos dan una prueba de su producto para convencer, algunos productos se muestran en su seriedad (la ropa) o en su dureza temporal (los metates, los molcajetes ${ }^{7}$ ), otros más requieren de discursos para mostrar sus propiedades curativas.

El tianguis es un mercado, su objeto es el intercambio comercial, pero el acto de vender y comprar en ese escenario emerge como un asunto de innovación motivado por la táctica del momento para lograr una mejor venta o una mejor compra. Es así que el regateo y la negociación son dos componentes propios del tianguis. El esfuerzo personal que se debe invertir en la interacción comercial del mercado itinerante es un acto permanente y cotidiano. Estas formas de mercadeo contrastan con las cualidades serias y menos festivas del mercadeo expresado en sus formas de mercado fijo, de supermercado $y$ de mercado de elite.

Para Castillo, los principales elementos del tianguis actual son: poseen un soporte material como la plaza, calles e infraestructura (camiones, carretillas, lonas, cajas, etc.) y el conglomerado humano que asiste al tianguis (comerciantes, clientes, paseantes, autoridades, trabajadores complementarios e indigentes) $(1995,36)$. A esto se suma la concepción que las personas tengan con respecto al propio tianguis, lo que proporciona las formas y principios que regulan la actividad colectiva para su festivo funcionamiento.

Como se aprecia, el tianguis es la modalidad actual donde el trueque se puede realizar, es decir, el intercambio de bienes que algunas regiones producen $y$ otras no. Mientras que en las otras dos modalidades se ha convertido en una práctica marginal (el caso del mercado fijo) o simplemente inexistente (el caso del supermercado y del comercio de elite). Estas cualidades son significativas en la medida que plantean la posibilidad de una forma cultural de

$7 \quad$ Un molcajete es una vasija de piedra que se utiliza para las mezclas de salsas, generalmente de jitomate rojo, tomate verde, aguacate, chile verde, cebolla y ajo, mientras que un metate es una plancha de piedra que se utiliza para moler el maíz. estos sectores populares susceptible de vislumbrarse desde las relaciones comerciales.

\section{EL TIANGUIS Y LA COMPETENCIA POR LA DEMANDA CON OTRAS MODALIDADES DE MERCADEO}

Se ha inscrito el tianguis como una forma de mercadeo, es decir, de afluencia de oferentes $y$ demandantes en una modalidad de mercado para personas de bajo poder adquisitivo. Existen otras formas de mercadeo que compiten por la demanda $y$ en este proceso se deslizan estigmas sobre las formas de mercadeo del llamado tianguis. Estas formas de estigmatización generan una opinión pública que raya en la informalidad $y$ la ilegalidad (contrabando $y$ narcomenudeo) de las formas comerciales al incorporar mercancías de todas partes del globo. Estas distintas modalidades de mercadeo crean a su vez distintas formas de socialización cultural, generando un mercado segmentado en función de la clase social, las adscripciones culturales étnicas o las distinciones que da ser personas del campo o de la ciudad. En suma, los mercados itinerantes son parte de regiones con identidad, el mercado tianguis se convierte en un lugar de identidad antropológica ${ }^{8}$, además de ser una ocasión para el comercio (Auge 1996). Esta cualidad se observa en el hecho de que buena parte de los productos que se intercambian se destinan al fondo ceremonial de las comunidades, aspecto sobre todo observable en el mercado de Ixtlahuaca y perdido por completo en el de Toluca.

Surge la interrogante sobre las maneras en que los mercados itinerantes se ligan a la tradición de una región en el momento en que la competencia se instala en los albores

8 Quizás las otras modalidades de mercadeo también se estén constituyendo en lugares para fomentar y proyectar la identidad cultural, fenómeno no visible en los mercados fijos pero si en los de elite cuando los jóvenes se apropian de los grandes centros comerciales a los que asisten, no solo a los restaurantes sino también al cine o a simplemente estar allí. Este tipo de mercadeo será analizado posteriormente, por lo pronto se centrará en la modalidad tianguis. 
del lugar de itinerancia establecido ${ }^{9}$; en este mismo sentido, otra pregunta necesaria es ver si las otras modalidades de mercadeo —-más cercanas a la lógica capitalista empresarialno terminarán por marginalizar o eliminar al mercado tianguis, reduciéndolo al aislamiento y excluyendo a los sectores pobres que lo practican. Estas preguntas llevan a afirmar que los oferentes del mercado tianguis representan una resistencia hacia el mercado de bienes manufacturados, en la medida que ellos colocan allí los bienes alimenticios propios del corral y la recolección. Esta resistencia la han manifestado los oferentes de leña de otro mercado itinerante de la región; el de Tianguistenco ${ }^{10}$.

La comparación de los dos mercados remite a configuraciones sociales populares. Mientras que el de Toluca ha experimentado fuertes embates de los gobiernos, locatarios y empresarios de las otras modalidades de mercadeo; parece mostrar formas distintas de incorporar a las comunidades rurales y colonias populares, además de su singular incorporación al mercado global (mercancías de fantasía, fayuca, productos no originales o llamados "pirata"). Por su parte, el mercado de Ixtlahuaca parece más cercano a la configuración de una identidad regional de comunidades y pueblos que asisten a intercambiar bienes (aves de corral, frutos del huerto familiar $y$ de la recolección) y cultura (de cuya venta se destina al fondo ceremonial de la comunidad). Así, la trayectoria de las mercancías es clave para entender las articulaciones

$9 \quad$ Es claro que la competencia de mercadeo fija ofrece productos todos los días, mientras que el mercado itinerante solo lo hace una vez a la semana, lo que obliga a la innovación permanente y llevar los productos a menor precio o más frescos que las competencias establecidas. Pero una parte atractiva de la existencia de estos mercados deriva precisamente del hecho que rompen con la monotonía de la semana, lo que les da un carácter festivo.

10 En dicho mercado subsiste una fracción del mismo en que comunidades otomíes y tlahuicas hacen trueque de madera por mercancías de todo tipo. Una versión de sus dirigentes es que este tipo de mercadeo debe subsistir en la medida que el capitalismo pretende apropiarse de todo (entrevista a dirigente en noviembre de 2014). tanto de estos mercados con la economía campesina e indígena, como con el mercado global.

Por esta razón, surge la pregunta, desde la oferta (los que tienen un puesto y venden un producto determinado), sobre las formas singulares de integración global (Alarcón 2008). De la misma manera, desde la perspectiva de la demanda o del consumidor, la pregunta se centra en ver si el consumo es expresión de la elección de la sociedad a la que se quiere pertenecer (Douglas 2008)11, o más bien se trata de una alternativa para el consumo de familias pobres (urbanas y campesinas) que asisten al mercado itinerante como vendedores y compradores a la vez, como suguiere Beals (1967). Esta veta teórica lleva a reflexionar en la articulación de los mercados tianguis con las economías campesinas (Villela 1997 y Paré 1988), lo cual es interesante en la medida que las zonas rurales del centro de México forman parte de esta megalópolis, entendida como una región en la que se articulan zonas urbanas (metrópolis) $y$ zonas rurales en un modelo de expansión difuso (Nivón 2003), por lo que la articulación de las economías campesinas en los mercados itinerantes significa a la vez su integración al mercado global.

Siguiendo con esta hipótesis, se puede argumentar que el contexto megalopolitano, así como, la inserción de estos mercados en la economía globalizada, ha terminado por transformar la oferta, de tal modo que se encuentran junto a los bienes tradicionales del huerto y el corral familiar (vacas, cerdos, caballos, burros, borregos, chivos, guajolotes, gallinas, conejos, etcétera) y de la recolección (quelites, hongos, frutos silvestres, raíces, camotes, etcétera), hasta productos como películas, artículos de fantasía, aparatos electrodomésticos, ropa de

$11 \quad$ Hay en la actualidad una serie de tianguis que reproducen el modelo de instalación de un día a la semana $y$ venden productos de elaboración natural y producción ambientalista. Tanto oferentes como demandantes pertenecen a las clases medias urbanas $y$ en ese caso, puede ser aplicable la hipótesis que asigna al consumo una pertenencia sociocultural (Douglas 2008). No pasa así con los mercados tianguis de tradición antigua en que más bien son los sectores menos favorecidos, los pobres, los que asisten a comprar $y$ vender sus alimentos $y$ bienes de vida. 
maquiladoras regionales, muebles de distintos materiales, pero también se expenden aquellos animales típicos de Perú, inexistentes en México, como son las llamas, lo cual hace pensar en la plena articulación de la economía global de bienes de cualquier naturaleza. De esta forma, se puede adelantar, que hay al menos tres tipos de sujetos comerciales que asisten al mercado tianguis:

1) Oferentes (poseedores de un puesto. Centran su actividad en la venta de sus productos).

2) Consumidores (personas que solamente van a comprar bienes).

3) Oferentes y consumidores a la vez (personas que van a vender un bien y a comprar otros).

En esta dinámica se articulan estrechamente las economías populares, de las colonias urbanas y campesinas de tradición indígena, con la economía global, como apunta la hipótesis de este trabajo, pues la venta de los productos del huerto y la recolección permite el acceso al consumo de bienes de otras regiones del globo.

Desde la misma perspectiva y siguiendo la reflexión anterior, se pregunta hasta qué punto oferentes y consumidores configuran un gusto cultural colectivo (Douglas 2008) al proyectar un tipo de sociedad en el tianguis, o más bien se trata de una institución coactiva que determina los comportamientos individuales, generando tipos de consumidores segmentados en función de la oferta (mercados itinerantes, mercados fijos, supermercados, mercados de elite). Esta diferenciación de la oferta y la demanda había sido descrita por Alejandro Marroquín cuando distinguió a los mercados con infraestructura fija de los mercados itinerantes (1978). Lo que se busca hacer en el artículo es extender aquella tipología a los supermercados y los establecimientos de elite, lo que puede estar generando una demanda y oferta segmentada, característica de estos tiempos de modernidad líquida, como la anunció Bauman $(2006)^{12}$.

Si bien en estas condiciones megalopolitanas, los mercados itinerantes o tianguis aglutinan a campesinos que son oferentes $y$ demandantes a la vez (Beals 1967) se puede preguntar si las condiciones metropolitanas no han cambiado el origen de la oferta y la demanda. Creemos que en la actualidad se han insertado, al mercadeo itinerante, además de campesinos, sectores populares de la sociedad que andan en búsqueda de alternativas de vida, lo que ha cambiado los productos de manera sustantiva $y$ ha integrado en este tipo de mercadeo bienes producidos en regiones como China, por ejemplo. Esto se describe en el análisis comparativo de estos dos mercados. En este sentido, se puede ver que las políticas de ordenamiento territorial que terminaron por desplazar el mercado de Toluca también se han expresado en el cambio de bienes $y$ productos que se pueden encontrar allí, de tal forma que las trayectorias históricas de los mercados se ven influenciadas por los contextos metropolitanos y las reacciones gubernamentales que orientan sus políticas "de limpieza" del espacio público.

Se puede decir que estos dos mercados itinerantes o tianguis: a) incorporan economías campesinas al mercado global, b) intercambian bienes $y$ productos ya sea por dinero o por otras mercancías en lo que se conoce como el trueque, c) son semanarios en el sentido de su itinerancia, pues se instalan un día a la semana en un lugar determinado, d) realizan venta de productos del huerto o de recolección, actividad generalmente realizada por mujeres,

12 Los centros comerciales para las capas de alto poder adquisitivo estarían configuradas por una oferta de clase social o estatus alto que se insertan en ese mercado buscando lugares seguros y limpios donde la interacción cara a cara es mediada por una oferta seria, blindada a la negociación y el esfuerzo por convivir con la diferencia cultural, el consumo es plano en ese sentido, contrario al mercado tianguis que se presenta en su dimensión más expresiva cuando del regateo se trata $y$ de la "venta gritada" a los posibles consumidores. En este caso, las relaciones y las interacciones sociales se manifiestan muy intensas y las negociaciones cara a cara "explotan" en cada compra. 
e) se encuentran entrelazados al mercado global. Además, los tianguis se encuentran a la orilla de otras formas de mercadeo, es decir, f) se trata de un mercadeo que se realiza junto a establecimientos de comercio fijo, g) ha diversificado los bienes campesinos o rurales (incorporando productos populares de manufactura) de tal forma que se articula con los productos campesinos que podrían destinarse al autoconsumo y productos cuya elaboración manufacturera se hace para el mercado (Villela 2013), h) se establece así una segmentación de la oferta y la demanda según el tipo o modelo de mercadeo en el que se consuma, representando el tianguis un segmento de oferentes y consumidores. Esto ha llevado a la competencia con las otras formas de mercadeo que desean apropiarse de dicha demanda, independientemente del segmento social al que pertenezca, lo cual explica el patrón de que allí donde existe un tianguis, se establecen las otras modalidades de comercio ${ }^{13}$.

Por otro lado, los oferentes de los mercados itinerantes han establecido una serie de estrategias de mercadeo muy singulares. Malinowski y de la Fuente (2011) propusieron, desde la década de los cincuenta, una tipología de vendedores, entre los que resaltan: a) los propios (que son los que llevan productos de sus huertos), b) los regateadores (que son los que compran a los vendedores propios para luego vender en mayor cantidad y a precios más altos en el mismo mercado itinerante) y c) los ambulantes (vendedores propios y regateadores que ofrecen deambulando). Es interesante esta tipología y cabe agregar aquellos comerciantes

13 Este es un patrón en el valle de Toluca, por ejemplo, en el municipio de Toluca, se estableció un Wall Mart antes de que fuera removido al lugar que actualmente ocupa dicho tianguis; en el de Ixtlahuaca se ha establecido en el mismo municipio una marca llamada Bodega Aurrera que busca apropiarse de esta demanda campesina; en otros municipios como San Felipe del Progreso ha sucedido lo mismo; en municipios Atlacomulco y Santiago Tianguistenco no solo eso, sino también se han asentado plazas comerciales para ir generando un consumo de elite regional. Este patrón es interesante $y$ sin duda está generando nuevas formas culturales definibles por los lugares y segmentos de consumo. propios que "desdoblan" a la familia para insertarse por las venas internas del mercado para vender el producto, de manera ambulante, lo que genera potencialidad a la venta familiar.

Una pregunta con la que se inicia esta investigación consistió en sí estos mercados tianguis conformaban sistemas concéntricos de comercio que aglutinaran a oferentes y demandantes en algunos de ellos, pero la evidencia empírica indicó que no es así, pues los casos aislados no conforman un patrón.

\section{CONTEXTOS PARTICULARES DE LOS MERCADOS ITINERANTES DE TOLUCA E IXTLAHUACA}

La hipótesis del trabajo pretende articular la economía campesina indígena y popular con el mercado global a través de la práctica del mercadeo en la modalidad tianguis o mercado itinerante. La decisión metodológica adoptada es la de comparar dos mercados itinerantes con gradaciones distintas de metropolización, de tal suerte que, si bien ambos se encuentran en medio de tal proceso, el de Toluca ha experimentado un embate permanente desde los gobiernos municipales, lo que caracteriza su trayectoria historiográfica y muestra los cambios de productos ofertados, mientras que el de Ixtlahuaca, más cercano a comunidades indígenas de tradición mazahua y otomíe, comienza a experimentar procesos similares a los del primero pero mantiene una articulación plena con la economía indígena y popular.

Los asentamientos en el Valle de Toluca tienen una historia larga que puede remontarse a los tiempos prehispánicos. Tanto el valle de México como el de Toluca fueron regiones siempre habitadas. La imagen 2 muestra la distribución territorial de los altepetls $^{14}$ prehispánicos en los dos valles y la adscripción étnica relativa. Todavía a

$14 \quad$ Un altepetl era una unidad político-administrativa propia del Estado prehispánico que aglutinaba a una clase dirigente, llamada los pipiltin, que sujetaban y dominaban a una clase inferior, llamada los macehuales (Broda y Carrasco 1985), organizada bajo el principio, ya anunciado por Zorita desde los primeros años de la conquista, del calpulli o barrio parental en línea paterna (Zorita 1942). 
principios del siglo xx era común encontrar un tipo de comercio entre los dos valles que se centraba en los productos lacustres (tule, patos, pescados, ranas, etc.) y productos manufacturados en la ciudad de México (García Sánchez 2008). De la misma manera, las comunidades asentadas en las serranías que bordean a la capital del país encontraban en el carbón, el producto que justificaba ir a vender e intercambiar bienes, allá por los rumbos de Tacuba y Tacubaya, zonas enclavadas en la ciudad de México.

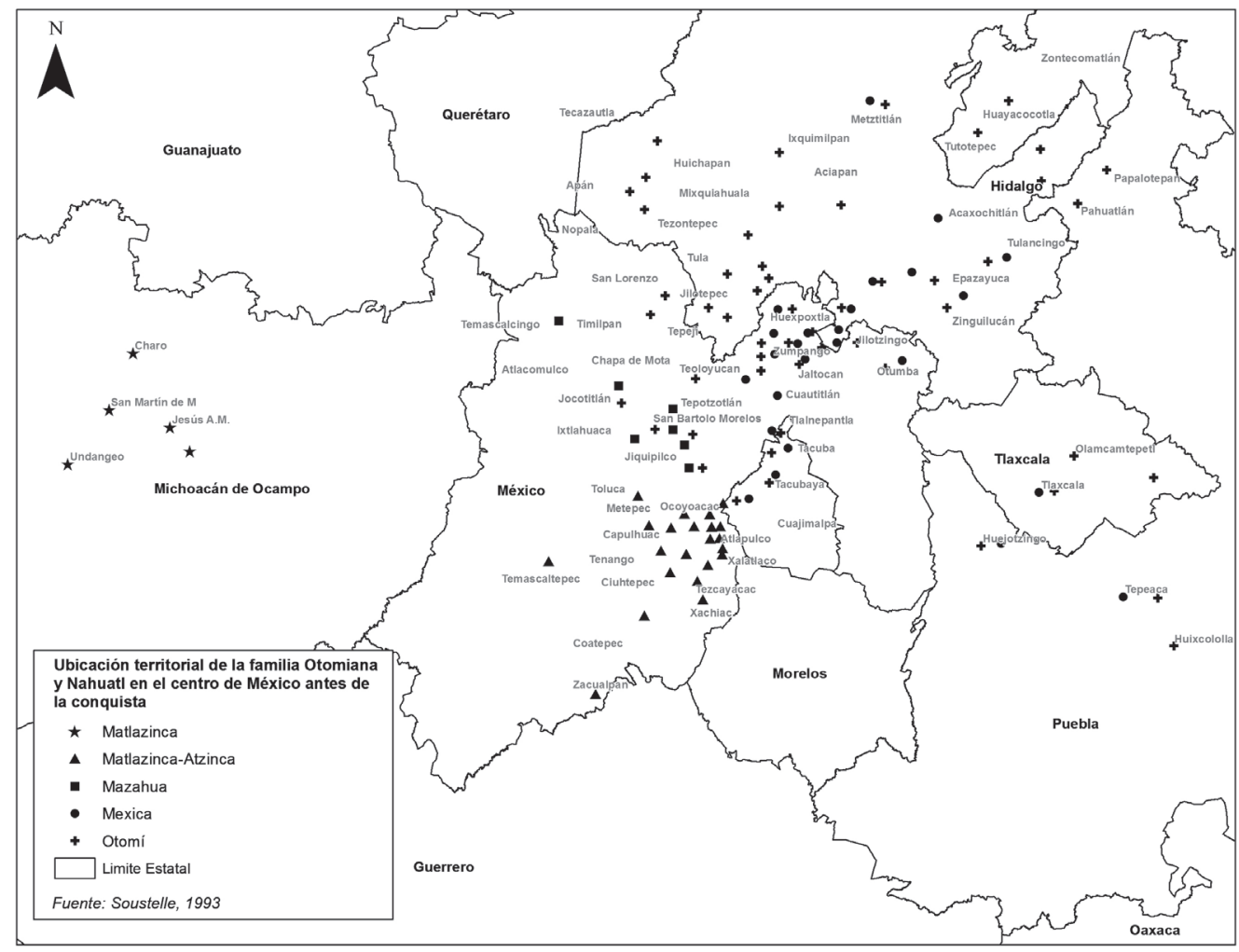

IMAGEN 2

UBICACIÓN TERRITORIAL DE LA FAMILIA OTOMIANA Y NAHUATL EN EL CENTRO DE MÉXICO ANTES DE LA CONQUISTA

Fuente: Soustelle, 1993.

Es importante anotar que esta región sobre la que se construye la megalópolis del centro del país estaba habitada desde los tiempos prehispánicos, es por eso que la tradición festiva de la zona es abundante a lo largo del año; las vocaciones agrícolas están en completo proceso de erosión cultural y las actividades lacustres están cediendo a actividades manufactureras propias del nuevo contexto (Albores 1995). La historia de la industrialización del Valle de México y del Valle de Toluca es la constante que estará en permanente tensión con la existencia de estas comunidades de orígenes étnicos.

Una cuestión que es importante resaltar es la articulación industrial de los valles de México y de Toluca. La política industrial que va de la década de los 40 a los 70 es ilustrativa de esto, en la medida que de los 139 parques industriales que se hicieron en México, 22,3\% (González Limón 1999) se hicieron en el territorio donde se encuentran estos dos mercados. La imagen 3 ilustra la emergencia de los parques industriales en el Estado de México y su respectiva fecha. 


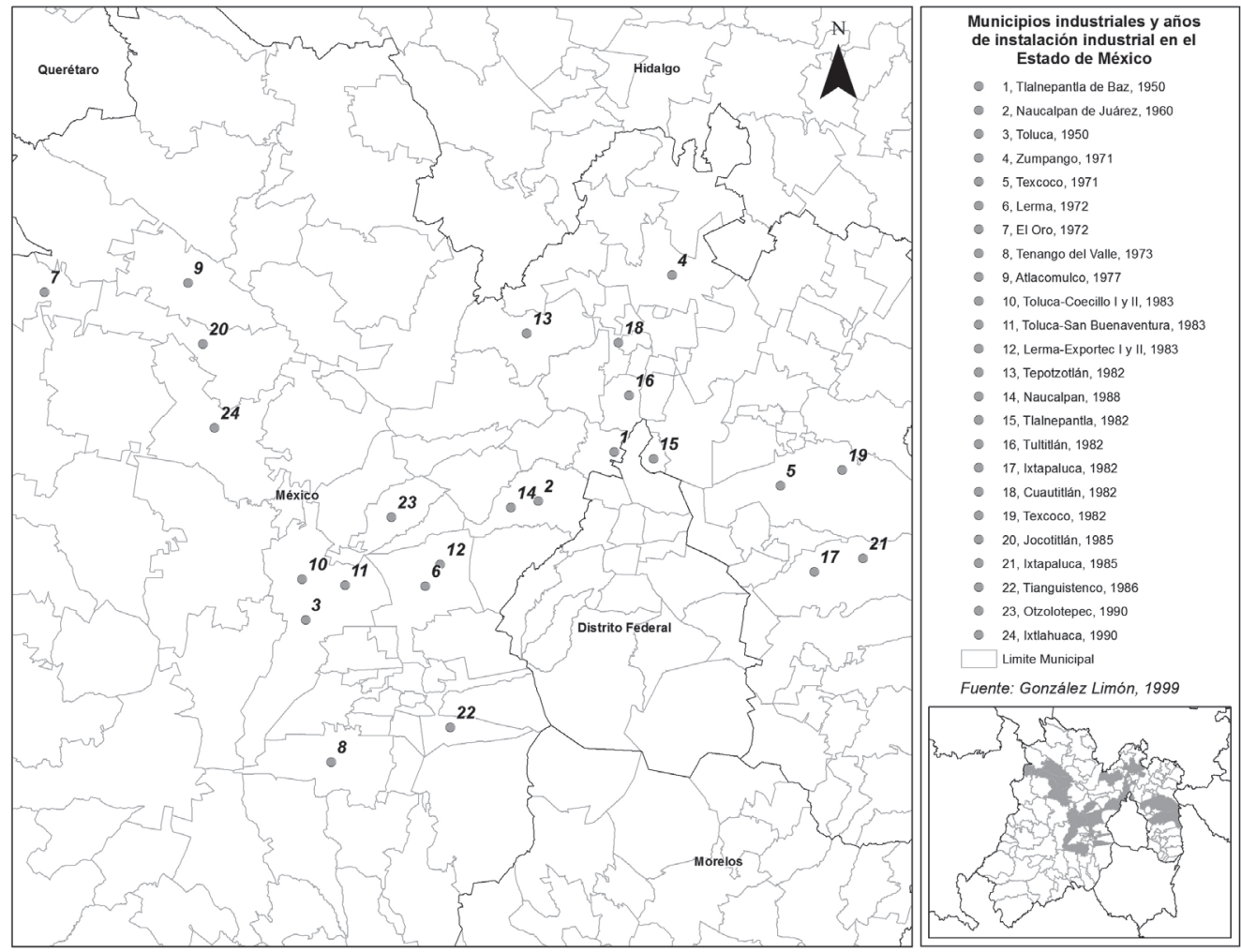

IMAGEN 3

MUNICIPIOS INDUSTRIALES Y AÑOS DE INSTALACIÓN INDUSTRIAL EN EL ESTADO DE MÉXICO Fuente: Gonzalez, 1999.

Entre los años de 1977 a 1982 emergen los parques industriales de Atlacomulco y continúa la consolidación industrial de Toluca; la década de los 80 significa la consolidación del parque industrial Lerma-Toluca. A su vez, este crecimiento industrial del Valle de Toluca es paralelo a la consolidación industrial en el Valle de México (Tepotzotlán, Naucalpan, Tlalnepantla, Tultitlán, Ixtapaluca, Cuautitlán y Texcoco). En la misma década, la industria se expande a Jocotitlán e Iztapaluca, Otzolotepec, Xonacatlán e Ixtlahuaca $^{15}$ (imagen 3).

15 En Megalópoli y cultura, del ritual indigena al performance urbano (2012), González Ortiz describe este proceso como una constante de cambio en la infraestructura espacial que termina transformando la dimensión cultural de los pueblos de
El crecimiento industrial del Estado de México ha localizado la industria en lugares donde existieron asentamientos humanos desde los tiempos prehispánicos. La imagen 4 ilustra los altepetls prehispánicos en el Valle de Toluca, comparando la imagen 3 y la 4 resalta la coincidencia entre la localización industrial y los asentamientos indígenas. Así, los habitantes de estas regiones han experimentado la llegada de nuevos vecinos a sus tierras, han cambiado sus vocaciones de trabajo $y$ han reelaborado los significados alrededor de los actos

origen prehispánico en dicha zona. Para efectos de este trabajo deben comprenderse dichos datos como parte necesaria para dar marco y contexto al estudio de los dos mercados. 
ceremoniales. Por ejemplo, la inserción laboral ha transformado las fechas del ceremonial colocándolas en los fines de semana y ya no en el día exacto de la celebración. Este cambio en las representaciones del tiempo ha desplazado la práctica agrícola como actividad complementaria al trabajo asalariado $y$ las formas culturales de celebración al santo patrón han incorporado nuevos actores como pueden ser los gremios laborales. Esta transformación de campesino (de tradición indígena) a obrero ha terminado por dar al bien agrícola, un significado residual en la trama cotidiana de los mercados itinerantes investigados.

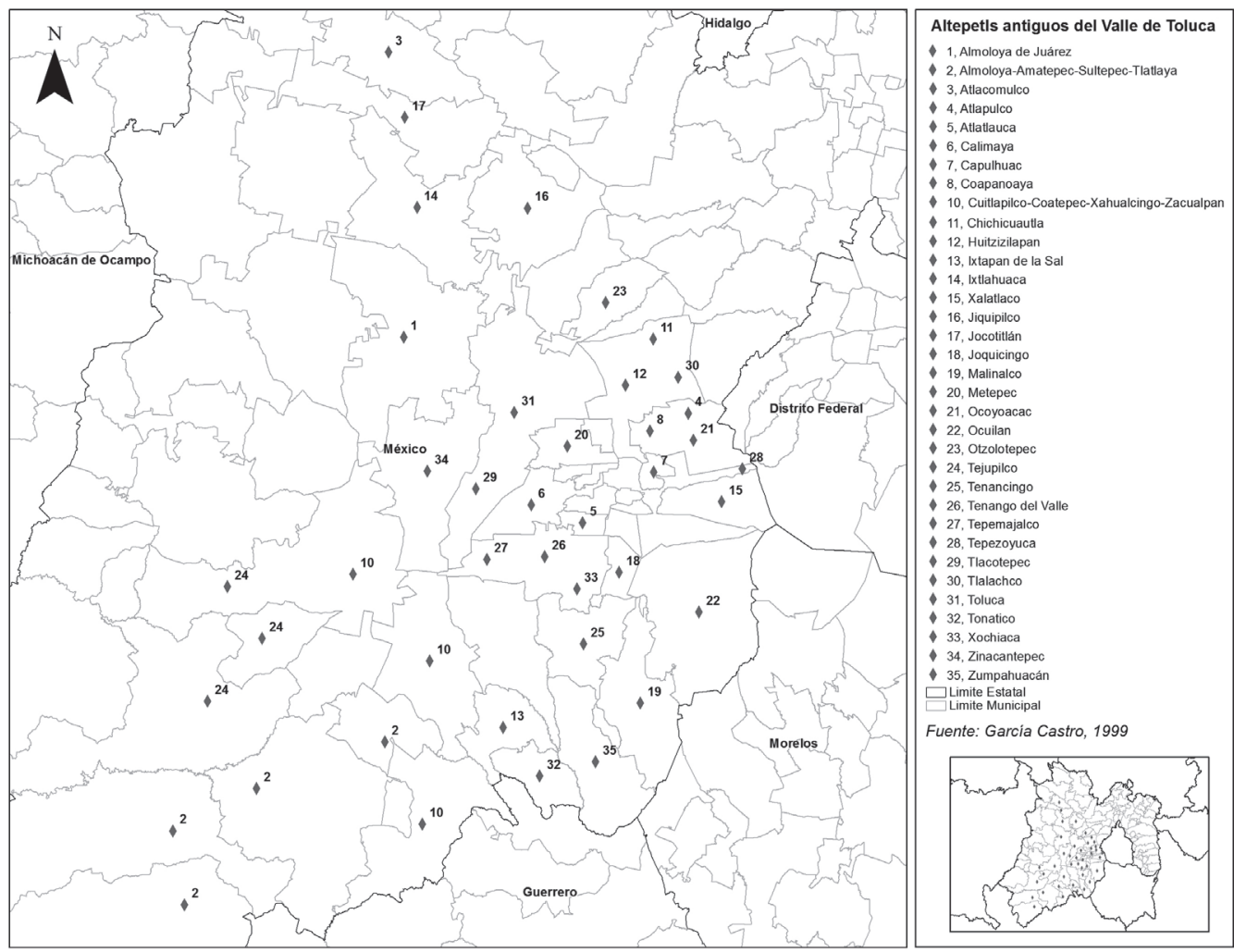

IMAGEN 4

ALTEPETLS ANTIGUOS DEL VALLE DE TOLUCA

Fuente: García, 1999.

\section{EL MERCADO ITINERANTE DE TOLUCA}

En un recorrido de 25 kilómetros al norte de la metrópoli de Toluca, hacia la salida a Ixtlahuaca, se asienta el mercado itinerante de Toluca. El aislamiento y la lejanía de la ciudad de Toluca es la más reciente característica de este mercado, pues esas son las dos marcas de su inicio, cuya centralidad era que su establecimiento se hacía todos los viernes en el centro mismo de la capital, hasta su actual alejamiento, en el cual la subsistencia en los márgenes es su marca más representativa.

Este proceso se acompañó de las reubicaciones que ha tenido siempre, en cuyas decisiones se encuentra el gobierno municipal, el cual sustentando sus acciones en las políticas de control del espacio público, lo ha reubicado en dos ocasiones, impactando en 
una desarticulación con la economía campesina indígena de la región.

La modalidad del tianguis representó la forma de mercadeo propio de la época prehispánica, en este sentido, el de Toluca corresponde a esta época (Romero, Viesca y Hernández 2011), asimismo, reúne a las diferentes comunidades y pueblos de las etnias mazahua, otomíe, matlatzinca, náhuatl y tlahuica, las que en la actualidad siguen asistiendo como oferentes y compradores a estos dos mercados ${ }^{16}$. En este periodo, siguiendo la lógica del intercambio, el trueque de madera por otros bienes era una constante.

Durante la época colonial, el tianguis de Toluca se transformó en su organización y funcionamiento internos, pues se introduce la noción de economía mercantil, en la que el dinero se convierte en la mercancía universal, desplazando paulatinamente la posibilidad del trueque. Estos cambios suponen un proceso de adopción y acoplamiento a nuevas circunstancias que van desde encontrar nuevos puntos de mercadeo que generan nuevas competencias, hasta la pérdida de características culturales propias del tianguis, tales como el trueque o la articulación de regiones para el intercambio, hasta la introducción y desplazamiento de productos ofertados y demandados. Este proceso encuentra solidez en el sentido que la modalidad tianguis ha tenido que sortear su existencia en contextos de relaciones sociales distintas que se pueden aglutinar en los bloques históricos prehispánico: el de la Colonia, el del México independiente, el México moderno y ahora en los tiempos de la globalización, dónde las economías campesinas indígenas y populares se articulan con la economía globalizada, según dicta la hipótesis de este trabajo.

De esta manera, durante la época de la Colonia existió una separación contundente entre la oferta de bienes y productos que se consideraban exclusivos para el consumo de los

16 No obstante, estos grupos culturales no se limitan a asistir a los dos mercados comparados, hay en el Valle de Toluca muchos más que se instalan en diferentes días de la semana, tales como el de Ocoyoacac, el de Tianguistenco, el de Metepec, entre otros. españoles y las mercancías vendidas por los indígenas, una forma de organización social propia de la época conocida como el repartimiento, separando a las regiones conocidas como las Repúblicas de españoles y las Repúblicas de indios $^{17}$. De esta manera, existía una regulación entre la producción y el consumo de mercancías propios de cada sector, así como, una marcada separación de los productos.

Un distintivo del Valle de Toluca en su carácter de región de frontera ${ }^{18}$, es que la producción de bienes y recursos naturales se destinó siempre al Valle de México, capital primero de la Nueva España y luego del México independiente. De esta manera, la producción del Valle de Toluca durante la Colonia, experimentó la introducción de ganado mayor, lo que originó la creación de grandes haciendas y latifundios dedicados a la producción de grano y ganado con la finalidad de abastecer al Valle de México. Este fenómeno económico fomentó una constante producción de carne y cereales para la población española y mestiza del centro del país. Como resultado de esta dinámica comercial, predominantemente española, se permitió que los indígenas mantuvieran cierta independencia sobre el comercio y distribución de sus productos, por lo tanto, el comercio del tianguis permaneció más o menos inalterado, pues permitía el intercambio de leña, pescados, tules, patos, aves de corral, etc. Así, productos españoles pueden considerarse el ganado mayor (cerdos, caballos, reses, chivos, borregos), mientras que los indígenas van desde leña hasta aves

17 En buena medida este modelo de organización política es la fuente de la segregación y segmentación social que se vive en México, lo que ha dado paso a las llamadas "gente de razón confrontada a la gente de costumbre" (Bartolomé 2004), matriz cultural clara del racismo implícito con el que se vive en México, filtrado incluso hacia las clases sociales, pues los más pobres son los menos blancos.

18 Una región frontera es aquella que define sus límites $y$ umbrales en función de otra región a la que surte de sus propios productos, en este sentido, las fronteras se daban por las especializaciones lacustres del Valle de Toluca frente a las manufacturas del Valle de México. Para una discusión sobre las regiones y las sociedades de fronteras, véase Fábregas (2010). 
de corral (gallinas y guajolotes), pasando por pescados, ranas, chiles, insectos y toda especie de quelites. En este sentido, se puede formular como hipótesis que los bienes que cada grupo oferta $y$ demanda configuran culturas, personalidades y estilos de vida; la biografía cultural de las cosas se define en función del grupo que las produce $y$ del grupo que las consume, ya que estos bienes poseen en ellos mismos una carga cultural (Kopytoff 1991).

En el México independiente, el mercado de Toluca de los viernes se hacía en el centro de la ciudad capital del actual Estado de México. Según las narraciones, había diversas zonas con venta de diferentes productos y bienes: ganado mayor, aves, verduras, insectos, hierbas, leña, comida, granos y cereales. Como puede verse, la segmentación de los productos de españoles de los de indígenas respondía al modelo de organización territorial que separaba ambas repúblicas, aunque en el México independiente estaba superado, las marcas de su pretérita existencia pueden observarse en la configuración de la venta de productos.

Según documentos históricos, desde 1834, el tianguis de Toluca se celebraba todos los viernes, primero en la actual plaza de los mártires, en pleno centro de la capital mexiquense $y$ después en los alrededores de la Iglesia del Carmen, donde permaneció de 1870 a 1974 (Castillo 1995). Después de ese año, se le reubicó a un costado del Mercado Juárez donde permaneció hasta el año 2006 para posteriormente llevarlo a las afueras de la ciudad $y$ al aislamiento en el que se encuentra en la actualidad, allá en la zona llamada Palmillas. Esta trayectoria de cambios y reubicaciones van acompañadas por el proceso de urbanización, industrialización y modernización del Valle de Toluca, procesos todos que conllevan nuevas necesidades a los habitantes. Por ejemplo, cuando en la década de los 70 , el mercado es desplazado a las afueras de la ciudad, allá en los albores de la terminal de autobuses, tanto la venta de animales de ganado mayor como de aves de corral desaparece por completo. Además se introducen nuevos bienes tales como ropa de mezclilla, tenis, zapatos, entre otros, desplazando paulatinamente a los de producción natural como los de tule, patos, ranas, ajolotes, pescados, todos bienes de las lagunas del Alto Lerma, los cuales terminan por desaparecer ${ }^{19}$. Este proceso desplaza los bienes del huerto y la pequeña granja doméstica, así como, los bienes producto de la recolección, por bienes manufacturados, dando entrada a una mayor dependencia al salario para la obtención de estos.

No obstante, el tianguis de Toluca mantiene su estructura de raíz prehispánica en la medida que representa el acceso de las familias pobres al mercado, a pesar de las reubicaciones de las que fue objeto. Por otro lado, es interesante observar las razones que se "deslizaron" para justificar estas reubicaciones, por ejemplo, la que ocurrió en 1974 se justificó debido a la problemática urbana que representaba la saturación de las calles en el centro de la ciudad, generando incertidumbre para los oferentes sobre el lugar de la nueva instalación, ya que no se conseguían las mismas ganancias. Castillo hace hincapié en la saturación constante de establecimientos, pues "para 1990 el tianguis había rebasado sus esquemas de operación constituyéndose en una nueva central de abasto" (1995, 73). El tianguis se mantuvo así al lado del mercado fijo de nombre Juárez y la central de abastos se reubicó en su dirección actual, allá a la salida a Naucalpan, antes de Xonacatlán.

La actual presencia del mercado tianguis de Toluca se aprecia cuando la carretera se densifica de autos, los estacionamientos se saturan de vehículos particulares, así como, camiones y camionetas que llevan los oferentes. Entre las características de este mercado se encuentran la constante humedad, el lodo de los pisos y la plancha de cemento sobre la que se instalan los

19 La implementación de la industria comienza en la década de los 60, como se vio en el apartado anterior, $y$ es un proceso que transformó la vida de las comunidades con una base de subsistencia campesina por una de carácter industrial, muchos de ellos se convertirán en campesinos, otros cambiarán sus actividades y maquilarán ropa y zapatos, y los demás se dedicarán a la fabricación de muebles. Para un estudio sobre estas transformaciones véase Albores (1995) y García Sánchez (2008). Para un estudio sobre las formas culturales de pueblos de tradición indígena en condiciones de metropolización, véase González (2009, 2012 y 2014). 
distintos puestos del mercado. Las estructuras tubulares de los puestos se disponen ancladas a la mencionada plancha para que los oferentes solo lleguen a colocar sus lonas sobre cada uno de los puestos para después disponer los productos. El mercado se distribuye por secciones según las características del producto, algunos pasillos se especializan en ropa, otros en mercancías de fantasía tales como anillos, aretes, collares y pulseras, otros más en comida tradicional mexicana (quesadillas, tlacoyos ${ }^{20}$, tacos), el lugar de las verduras y completamente marginado, al lado de baños, se ofrece el producto más indígena que subsiste a estos cambios: el pulque ${ }^{21}$. Asimismo, no hay mercado de ganado mayor ni de aves de corral.

Los pasillos de la ropa son silenciosos y obscuros, las prendas de vestir proyectan una moda urbana y moderna con ciertas marcas populares. Muchos de los oferentes poseen sus propias maquilas, generalmente en la ciudad de México y aprovechan la existencia de este mercado para vender sus ropas. Los zapatos y tenis también se encuentran en esta sección del mercado y buena parte de sus oferentes pertenecen a las manufacturas de San Mateo Atenco, municipio impactado por la desecación del Alto Lerma. Un asunto de importancia es la existencia de puestos que anuncian que reciben pago con tarjeta de crédito, cuestión que hace pensar que la idea del trueque es asunto del pasado. En este mismo tenor, hay algunos que venden al crédito los teléfonos celulares, lo que indica no solo innovación sino el hecho de meter a este tianguis en una dinámica menos tradicional y más urbana, llegando incluso a una difusa distinción de aquel origen indígena de este mercado itinerante.

En la salida de estos pasillos, el ruido anuncia la entrada a la venta de verduras y frutas. Si en la ropa la demanda era escasa, en las verduras es abundante. No obstante, el origen de los demandantes no se alcanza a distinguir completamente indígena, hay un componente

20 El tlacoyo es una tortilla gruesa de maíz con frijol, haba o queso.

21 Bebida alcohólica sacada de un tipo de maguey distinto del tequilero y mezcalero. urbano que lo simula; vienen de las colonias populares de la ciudad de Toluca, algunas de ellas transformadas en colonias pero de orígenes indígenas como Zopilocalco o La Teresona, pero también de los pueblos indígenas otomíes de San Pablo Autopan y San Cristóbal Huichochitlán y de otros pueblos pertenecientes al municipio de Villa Victoria, donde habitan los mazahuas. Es interesante que los habitantes de estos pueblos sigan asistiendo a comprar sus alimentos a este mercado; no obstante, algunos consumidores comentan que antes venían más seguido pero que ahora van a otros mercados, incluida la central de abastos que se encuentra en la ciudad de Toluca. La negociación y el regateo forman parte de este escenario. Un oferente comenta que antes la venta era mucho mayor, que en este nuevo lugar las ventas bajaron significativamente.

Entre los pasillos se observa una virgen de Guadalupe montada en un carrito de cuatro ruedas. Un oferente señala que el dueño de aquella virgen es un puestero; no obstante, al consultar en el lugar, nadie reconoce la posesión de la virgen. Asimismo, se preguntó si esta imagen no es de varios puesteros y contestan que no, que en su anterior localización, varios puesteros se encargaban de una virgen de Guadalupe a la que le hacían su fiesta y la guardaban todos los días en el mercado fijo, pero ahora, acá en el aislamiento, es difícil guardar la imagen, por eso la responsabilidad de tenerla es individual. Sin duda el paso de una posesión colectiva de los santos a otra individual es una marca propia de un mercado que ha transitado de la centralidad a la marginación, de la luminosidad a la opacidad, de la conexión al aislamiento.

Al lado del área de las frutas y verduras se encuentran los establecimientos de comida, en las cuales se unen los gritos, los colores y la densidad de los olores haciendo llegar a las manos de los potenciales consumidores, pequeñas pruebas para elegir este o aquel puesto del mercado. Se acompañan los platillos con cerveza o refresco, pero para culminar se elige un pulque, no obstante, los puestos se encuentran al lado de los baños. Se observa en esta situación que los productos indígenas se encuentran 
subordinados, nulificados y desplazados. Por otro lado, no hay mercado de ganado mayor ni de aves de corral. El carácter urbano-popular de este mercado se enseñorea como parte de su personalidad dominante.

La última sección del mercado aglutina a mercancías de plástico y metal. Se trata de mercancía de fantasía y herramientas que vienen de Asia en su mayoría. Se puede observar el contrabando, la fayuca, a la mercancía que se encuentra vinculada con el mercado global, con las economías emergentes y el capitalismo global.

El trueque ha desaparecido por completo. Cuando este tianguis se encontraba junto al mercado Juárez se mantenía una relación directa de intercambio entre los productores campesinos y los consumidores, pues aglutinaba todavía a comunidades indígenas de los perímetros urbanos, pero esta relación disminuyó considerablemente cuando se trasladó al aislamiento de Palmillas, en la carretera de la salida de la ciudad. La historiografía de las reubicaciones de este mercado puede referirse como el cambio en las configuraciones culturales que los productos le daban. Así, por ejemplo, en el primer traslado, el que va del centro de la ciudad de Toluca a la zona de la terminal de camiones, en los albores del mercado Juárez (en la década de los 70), se dejaron de vender animales de corral, frutos del huerto $y$ bienes de la recolección, es decir, casi la totalidad de los bienes campesinos. Esto contrasta con el mercado de Ixtlahuaca, por ejemplo, un vendedor de carpa ${ }^{22}$, señaló que no asistía al mercado de Toluca los viernes: "cuando se encontraba en la ciudad de Toluca siempre íbamos, pero ahora que está en Palmillas no, pues no se vende igual". La ausencia de esta articulación con la economía campesina es de suma importancia para el análisis comparativo.

Existe una transformación constante en el tianguis de Toluca que se relaciona con la reorganización en función del espacio. Esto provoca que se desarticulen los elementos de tradición prehispánica, haciendo que subsistan

22 La carpa es una clase de pescado de agua dulce que se cosecha en las presas de la región, especialmente en la presa de Villa Victoria, zona perteneciente al pueblo indígena Mazahua. como restos del intercambio de comunidades indígenas y campesinas en ciertos puntos del tianguis, aunque en espacios marginales (como fue el ejemplo del pulque). En el tianguis de Toluca, los comerciantes venden todo tipo de productos que no necesariamente llegan de las comunidades campesinas, no existen restricciones en cuanto a la venta, pues se han modificado los actores en conjunto con los productos, con la finalidad de lograr el crecimiento metropolitano del Valle de Toluca. Miller argumenta: "que tan pronto como las sociedades entran a la economía mundial, deben asumir un abandono de sus identidades $y$ derechos históricos para entrar a la lógica de la homogeneización del consumo, que termina normalmente en una considerable pérdida de la cultura" (citado en Alarcón 2008, 156).

\section{EL MERCADO ITINERANTE DE IXTLAHUACA}

En el mismo Valle de Toluca se encuentra el Municipio de Ixtlahuaca. El día de la semana que se instala este mercado es el lunes, el cual se encuentra con diversidad de actividades mercantiles, pues la totalidad de la cabecera municipal se encuentra abarcada por puestos comerciales. Ixtlahuaca se encuentra a 60 kilómentros de la capital del Estado y su traslado es relativamente rápido. De la misma manera, este municipio se erige como la entrada a la zona étnica mazahua. El tipo de asentamiento urbano responde a la lógica de dominación territorial y política llamada zona de refugio (Aguirre 1987), es decir, se trata de una cabecera municipal que concentra la actividad económica y una serie de comunidades satélite que gira en torno a la cabecera, centro regional del poder político y del poder económico ${ }^{23}$. Esta observación la había hecho Marroquín en su libro sobre Tlaxiaco, la ciudad mercado (1978).

23 La centralidad del poder económico se observa mediante el acaparamiento de establecimientos comerciales de grandes dimensiones, así como de las profesiones, por parte de los herederos de los criollos, mientras que el poder político deriva de la forma caciquil pero ahora articulada con los partidos políticos. 
Afuera de la terminal de autobuses y desde temprana hora de la mañana, existe un movimiento de personas que llegan cargando sus productos para la posterior venta $y$ se organizan los puestos de semillas como maíz, frijol, garbanzo y habas, en costales rectangulares. Los vendedores son muchos pero se resalta que la mayoría son parejas de ancianos, quienes afirman comprar en otras regiones.

Una serie de puestos de cerámica se encuentran en la zona. Los oferentes afirman que su origen es de las comunidades mazahuas del vecino Municipio de San Felipe del Progreso, pero que esta artesanía la traen de Tonalá, Jalisco. Con esta respuesta se puede inferir que este tipo de mercadeo itinerante es de suma importancia para el mercado interno y conecta regiones del país que otros mercados no hacen, aspecto mencionado por Enriqueta Quiroz (2013) ${ }^{24}$, acorde con la hipótesis de este trabajo. A la pregunta sobre las razones de no traerla del municipio vecino de Metepec, metropolizado a Toluca, su respuesta dice que la calidad es mejor en la cerámica de Tonalá y que su venta es mayor. Es interesante anotar cómo los mercados aglutinan y proyectan el mercado interno nacional de los productos más variados. En esta misma dinámica se encuentran los muebles que traen unos comerciantes provenientes de Michoacán.

Asimismo, se encuentran los puestos de barbacoa, entre ellos se empiezan a poner los puestos de pulque, resaltando que en el mercado de Ixtlahuaca poseen un lugar central, frente a la comida. Frente a esta zona de comida está instalado el mercado tradicional fijo, otra modalidad de mercadeo y atrás, a unos trescientos metros de distancia, se encuentra el supermercado de nombre Bodega Aurrera.

24 En otro mercado itinerante que se instala los martes en la cabecera municipal de Santiago Tianguistenco, se encuentra a hombres y mujeres del pueblo indígena de Oaxaca llamado triqui. Ellos estaban comprando productos de lana que se elaboran en la comunidad otomíe conocida como Gualupita y decían que después las revenderían en el mercado itinerante de San Juan Copala, en la región triqui de Oaxaca, a un precio mayor. Esta es una manifestación de mercado interno pero con la modalidad de relaciones interétnicas mercantiles.
Estas dos modalidades de mercadeo comienzan la competencia con el mercado tianguis, esta experiencia fue documentada en la trayectoria historiográfica del mercado itinerante de Toluca, que terminó perdiendo ante estas otras dos modalidades de mercadeo y "lanzado" al aislamiento mercantil $y$ a la indiferencia social de los demandantes.

Este tianguis se instala en la totalidad de la cabecera municipal y se diversifica según los productos ofertados. Hay una zona de animales ubicada en un extremo de la región urbana de la cabecera municipal. En esta se puede observar una serie de señoras y parejas de ancianos que ofrecen aves de corral como guajolotes, patos, gallinas y gallos, pero también encuentran palomas domésticas y conejos. Los oferentes pagan un derecho a una administradora para realizar sus ventas. El demandante de aves generalmente las utiliza para el ceremonial festivo en su comunidad, pues es común que se tenga una deuda que pagar con un guisado de mole de guajolote con arroz o pollo en mole con arroz. La presencia de las aves en este mercado es una marca precisa del mundo indígena, es decir, se trata de un grupo de oferentes que vienen de alguna comunidad en particular a ofrecer sus aves, los demandantes llegan a adquirirlas debido a que se "atraviesa" un ceremonial en sus comunidades ${ }^{25}$. La dimensión cultural de los bienes encuentra aquí su mayor expresividad, pues estos bienes forman parte de un circuito cultural que determina tanto su oferta como su demanda, en la medida que se insertan en los productos usados para el ceremonial festivo de las comunidades.

Es importante hacer una breve descripción para explicar la oferta y la demanda de aves de corral en los tianguis y la composición indígena de estos productos. La vida ritual y festiva en las comunidades indígenas puede sintetizarse en dos ciclos ceremoniales; los que responden a la actividad comunitaria (los santos, los carnavales, las peregrinaciones a los santuarios) y las que derivan de las familias,

$25 \quad$ Jacques Galinier dice que entre los mazahuas, el guajolote es el ave sacrificada que genera los lazos de parentesco ritual entre familias, el inicio de nuevos ciclos de relaciones sociales y culturales (1990). 
de los grupos domésticos extensos (Dow 1990 y Galinier 1990a) que generalmente tienen que ver con los rituales de paso (Van Gennep 1986). En el primer tipo de ceremonial, los mayordomos ${ }^{26}$ deben ofrecer a los invitados comida y generalmente, esta se compone de gallinas y guajolotes combinados con moles $y$ arroz. La propia estructura de la organización social para el ceremonial genera una serie de solidaridades con los miembros de la mayordomía quienes, desde ese momento, se encuentran en deuda con sus parientes $y$ vecinos que le ayudaron a cumplir con el ceremonial comunitario, de tal forma que cuando a algún vecino o pariente le toque ser mayordomo, este le retribuirá exactamente la misma cantidad con la que se le ayudó.

Lo mismo sucede con el ceremonial de los grupos domésticos en extenso, en ocasión de una fiesta de 15 años o de un matrimonio, una confirmación o un bautismo, los parientes $y$ vecinos contribuyen con los guisados de aves, tortilla, arroz y mole, lo que dada la ocasión, la familia apoyada deberá responder con idéntica reciprocidad a la familia que realice el ceremonial de paso. Esta estructura de reciprocidades rituales genera un mercado intracomunitario en el que las aves juegan el papel central de la reciprocidad.

Lo mismo sucede con la sección de flores. En el mercado de Ixtlahuaca hay una gran sección dedicada a la venta de flores, en la mayoría de los casos se vincula con el ceremonial festivo, sobre todo en el comunitario, que implica comprar flores para adornar la fachada de la iglesia, para llevar dentro de la iglesia y mantener los nichos de los santos adornados. Los oferentes vienen desde el sur de la entidad, además de pro-

26 Mayordomo refiere al nombre de la organización social para el ceremonial propio de las comunidades indígenas, es decir, se trata de un equipo de vecinos de la comunidad encargados de realizar la fiesta patronal del pueblo. ductores de flores de otras regiones como son Atlacomulco y Michoacán.

En el mercado de animales emerge el ganado mayor: cerdos, vacas, toros, borregos, chivos y caballos. Sus oferentes también provienen de las comunidades del interior de la región mazahua y los animales de esta sección tienen varias funciones en la lógica mercantil y su articulación con los modos de vida de las comunidades indígenas. Si se trata de un borrego, un cerdo o un chivo, seguro se destinará al ceremonial festivo del grupo doméstico o familia extensa; una vaca a la producción de leche, un toro para la yunta, un caballo o una mula para el transporte o la yunta. Anteriormente, el burro se vendía en mayor cantidad, pues servía para transportar productos del campo (costales de grano, pastura, leña); no obstante, han sido sustituidos por camionetas que hacen el mismo trabajo.

La inexistencia de esta sección en el mercado de Toluca es una diferencia importante de señalar. Se puede afirmar que la inexistencia de esta sección mercantil significa una desarticulación completa con la lógica de vida cultural de las comunidades indígenas. Ahora bien, tanto el proceso de crecimiento urbano metropolitano como la competencia con otras modalidades de mercadeo pueden ser variables que expliquen este fenómeno.

La zona de las verduras y frutas es acompañada por los gritos de la negociación y el regateo. Asimismo, se escuchaban cánticos religiosos y entre los puestos emerge el campaneo constante $y$ rítmico de un instrumento musical que acompaña los rezos, lo cual anuncia la llegada de peregrinos que vienen de San Antonio de las Huertas, una comunidad mazahua de la montaña, en el Municipio de San Felipe del Progreso, que van con el Señor del Cerrito, un santuario ubicado en el Municipio de Jiquipilco ${ }^{27}$. Se pudo observar que un joven

$27 \quad$ Para un estudio detallado sobre esta peregrinación, véase González Ortiz (2008). 
cargaba un nicho con las imágenes de los santos a venerar $y$ una señora carga el sahumerio del que sale humo permanentemente, llenando la atmósfera de olor a copal. En este sentido, es evidente la diferencia con el mercado itinerante de Toluca, en el cual este tipo de ceremoniales no se presentan, su aislamiento lo ha llevado a esta situación al grado que la virgen de Guadalupe que mantienen, es objeto de negación por parte de sus usuarios y propietarios, pues muchas veces negaron ser los orquestadores de la presencia de aquella imagen.

En la sección de venta de ropa, los oferentes se muestran callados. El espacio entre pasillos es más amplio y la circulación de personas menos densa. Los productos en este mercado, según los oferentes, no son propiedad de maquilas de ellos mismos, sino más bien se trata de intermediarios que compran la ropa para después revenderla en este mercado. Diferencia importante con el de Toluca, en el cual la maquila en la ciudad de México es una constante para luego revender los viernes el producto terminado ${ }^{28}$.

Finalmente, la sección de discos y artículos de fantasía no es abundante -en comparación con el de Toluca- sin embargo, esta entrando fuertemente este tipo de mercancías. Se resalta en la oferta de discos - piratería-, historias de narcotraficantes o miembros de la delincuencia organizada, películas mexicanas de policías y ladrones (los hermanos Almada, Lola la Trailera, etc.) y películas de Hollywood.

28 Lo mismo se observa en el mercado de Santiago Tianguistenco, que se instala los martes y que también pertenece al Valle de Toluca, solo que en este la maquila la hacen en el Municipio de San Mateo Atenco, ya sea de ropa o de zapatos. Es importante mencionar que los habitantes de este municipio fueron los afectados por las políticas de industrialización del Valle de Toluca, específicamente en la región del Alto Lerma, lo que orilló a sus habitantes a dedicarse a actividades distintas a la producción lacustre, entre las que se encuentra la maquila (Albores 1995 y García Sánchez 2008).
Una sección que no existe en el mercado de Toluca es la de productos silvestres recolectados. Se trata de frutos silvestres como duraznos, tejocotes, capulines y moras, de variedades de hongos $y$ de hierbas comestibles como quintoniles, malvas o quelites. Estos productos son recolectados principalmente por mujeres y llegan al mercado a venderlos como bienes propios de la región para los guisados y los alimentos. Los vendedores comentaron que existía en las comunidades aledañas del mercado itinerante de Toluca, pero el proceso de urbanización terminó con estos bienes de recolección a tal grado que en la actualidad ni siquiera se pueden encontrar en las regiones más aisladas. Una señora del mismo mercado de Toluca comentaba que antes había muchos productos para el consumo que se podían encontrar en el campo, pero que ahora casi todos los productos deben ser comprados. Este comentario habla de una integración más completa al mercado de dinero para adquirir los bienes, lo cual convierte a la recolección en una trinchera de resistencia al mercado capitalista acabado, como se comprueba en el mercado de Ixtlahuaca.

\section{CONCLUSIONES}

Se pueden observar varias diferencias y similitudes que presentan estos dos mercados itinerantes. El estudio de estas modalidades de mercadeo significa establecer las articulaciones o yuxtaposiciones de los mismos respecto a las economías campesinas indígenas, por un lado y a la economía globalizada, por el otro. De ahí que el estudio de las trayectorias de estos dos mercados itinerantes aportó elementos para su comparación y para observar los grados de articulación con estas dos instancias (la economía campesina indígena y la global). El siguiente cuadro ilustra de manera general las diferencias y similitudes. 


\section{CUADRO 1 \\ DIFERENCIAS Y SIMILITUDES ENTRE LOS MERCADOS ITINERANTES DE TOLUCA E IXTLAHUACA}

\begin{tabular}{lcc}
\hline & MERCADO & MERCADO \\
& DE TOLUCA & DE IXTLAHUACA \\
\hline Venta de productos de fantasía y fayuca & Muy presente & Poco presente \\
Uso de tarjeta de crédito & Poco presente & Ausente \\
Venta de animales de corral & Ausente & Presente \\
Venta de bienes de recolección & Ausente & Presente \\
Venta de productos para usar en el ceremonial campesino & Ausente & Presente \\
Articulación con la economía campesina indígena & Poco presente & Muy presente \\
Articulación con la economía globalizada & Muy presente & Poco presente \\
Existencia del trueque & Ausente & Poco presente \\
Trayectorias de conflicto $y$ desplazamiento & Presente & Ausente \\
\hline
\end{tabular}

Fuente: Elaboración propia con base en trabajo de campo.

Es importante anotar que una conclusión que aporta al conocimiento de los mercados itinerantes es reconocer que este tipo de mercados, al ser expresión de la venta de los productos campesinos, se convierten en arenas para el intercambio de bienes alimenticios de diversos pisos ecológicos — de esta suerte que se posibilita el trueque- distinto a los bienes propios de la economía global en donde el dinero se convierte en la única posibilidad del intercambio.

Algunas diferencias y similitudes a anotar entre los dos mercados es el hecho de que la existencia de productos de fantasía y de fayuca (o contrabando) son de dimensiones distintas, pero en ambos existen; es decir, los dos mercados se encuentran atravesados por una clara articulación con la economía del mundo. Así, se puede afirmar que la globalización contribuye a configurar la modalidad de comercio llamada tianguis en este nuevo contexto de economía global (siempre con el peligro de llegar al umbral de ser estigmatizado como comercio informal o ilegal).

Marcas fundamentales de integración a la economía mundial son, por ejemplo, que en el mercado de Toluca se encuentra una paulatina entrada al pago con tarjeta de crédito, es decir, una invasión del tipo de mercadeo de elite $y$ de supermercado que se manifiesta por las terminales electrónicas dispuestas en algunos puestos de dicho mercado. Este tipo de pago no se encuentra ni en la sección de ropa, la aparentemente más seria del mercado de Ixtlahuaca.

La existencia del mercado de Ixtlahuaca desde tiempos antiguos es un hecho que se debe resaltar y las formas de articulación de las economías campesinas, un factor clave para entender específicamente a este mercado. La existencia de los productos que se articulan con el ceremonial festivo de las comunidades (tales como animales, ceras o productos de la recolección), es un indicador de esto, lo que paulatinamente se perdió, según se observó en la trayectoria histórica del mercado itinerante de Toluca.

La comparación entre estos dos mercados ha servido para "lanzar" una hipótesis sobre la trayectoria de los mercados itinerantes en situaciones contextuales caracterizadas por intensos procesos de metropolización. Se parte de reconocer la posibilidad de que esta modalidad de mercadeo articulaba dos instancias, a las economías campesinas y al mercado global. Se observó que el mercado de Toluca perdió su articulación con la economía campesina a través de las comunidades indígenas. Esta situación contrasta con el mercado de Ixtlahuaca, pues en este la presencia de animales de ganado mayor 
$y$ de aves de corral son una muestra de su articulación con la comunidad campesina (como se indicó antes, estos animales se destinan al ceremonial de la comunidad). En este sentido, la hipótesis de Paré (1988) y Villela (1997) se debe poner a prueba en este tipo de casos.

Así, los vínculos de las comunidades con una mayoría de presencia indígena mantiene una relación directa con las formas del tianguis tradicional. De esta manera, las personas que comercializan en el tianguis tradicional, mantienen una práctica de subsistencia comercial, pues el intercambio se basa en alimentos y no en excedentes de producción, con lo cual se da la existencia de una relación directa entre la agricultura de subsistencia practicada en distintas comunidades $y$ el intercambio comercial en el tianguis.

La vinculación entre la economía campesina con el mercado global no se encuentra del todo articulada, en todo caso yuxtapuesta, es decir, los bienes campesinos subsisten en el mercadeo paralelamente a los bienes industriales globalizados. Esta subsistencia puede llegar a transmutar en competencia a grado tal que los tianguis se conviertan en prácticas vulnerables que contradicen las políticas del comercio "formal", manifiesto en otras modalidades de mercadeo tales como, el supermercado o el mercado de elite, lo que convierte al tianguis en objeto de política urbana, lo cual se ha constatado en la trayectoria del mercado itinerante de Toluca en que se ha visto reubicado.

Este aislamiento se acompañó primero de estigmas elaborados desde los gobiernos locales (ilegalidad, informalidad, evasión al pago de impuestos, etc.), para luego instalar otras modalidades de mercadeo (en este caso el supermercado Walmart) que compiten por la demanda segmentada a este tipo de mercados y finalmente, aislarlos. ¿Cuáles serían las razones para estas acciones? El objeto es que todos los demandantes $y$ oferentes entren a las relaciones sociales mercantiles en que el dinero es la expresión última de las relaciones sociales, como decía Simmel desde principios del siglo xx (1977). De esta manera, se trata de que el trueque y la venta de productos recolectados se subordinen a la esfera del dinero, es decir, de la oferta y la demanda capitalista. El estudio de estos dos mercados itinerantes da las pistas de una especie de arqueología del mercado para dilucidar las intenciones del mercado y del Estado moderno.

\section{BIBLIOGRAFÍA}

LIBROS

Aguirre Beltrán, Gonzalo. 1987. Regiones de refugio. México: Instituto Nacional Indigenista (INI).

Alarcón, Sandra. 2008. El tianguis global. México: Universidad Iberoamericana.

Albear Acevedo, Carlos. 2004. Historia de México. México: Limusa.

Albores Zárate, Beatriz. 1995. Tules y sirenas. El impacto ecológico y cultural de la industrialización en el Alto Lerma. México: El Colegio Mexiquense.

Auge, Marc. 1996. Los no lugares, espacios del anonimato. Una antropología de la sobremodernidad. Barcelona: Gedisa.

Bartolomé, Miguel. 2004. Gente de costumbre y gente de razón. Las identidades étnicas en México. México: Siglo xxı.

Bauman, Zygmunt. 2006. Modernidad líquida. México: Fondo de Cultura Económica-Fce.

Broda, Johanna y Pedro Carrasco. 1985. "La economía del México prehispánico". En Economía política e ideología en el México prehispánico, coordinado por Pedro Carrasco y Johanna Broda, 15-76. México: Nueva Imagen.

Castillo Nechar, Marcelino. 1995. El tianguis de Toluca: una reminiscencia de los mercados prehispánicos. México: Universidad Autónoma del Estado de México-uaEMex.

Díaz del Castillo, Bernal. 2012. Historia verdadera de la conquista de la Nueva España. Barcelona: Red Ediciones.

Douglas, Mary. 2008. Estilos de pensar. Barcelona: Gedisa.

Dow, James. 1990. Santos y supervivencias. México: Instituto Nacional Indigenista (INI).

Fábregas Puig, Andrés. 2010. Configuraciones regionales mexicanas. Un planteamiento 
antropológico. México: Gobierno del estado de Tabasco.

Galinier, Jacques. 1990a. La mitad del mundo. Cuerpo y cosmos en los rituales otomíes. México: Universidad Nacional Autónoma de México (unam).

García Castro, René. 1999. Indios, territorio $y$ poder en la provincia matlatzinca, la negociación del espacio político de los pueblos otomianos, siglos XV-XVII. México: El Colegio Mexiquense, Instituto Nacional de Antropología e Historia y Centro de Investigaciones y Estudios en Antropología Social.

García Sánchez, Magdalena A. 2008. Petates, peces y patos. Poervivencia cultural y comercio entre México y Toluca. México: Centro de Investigación y Estudios Superiores en Antropología Social (CIEsas).

Garza, Gustavo. 2000. "Ámbitos de expansión territorial". En La ciudad de México en el fin del segundo milenio, coordinado por Gustavo Garza, 237-246. México: El Colegio de México y Gobierno del Distrito Federal.

González Ortiz, Felipe. 2008. Un pueblo que camina. Peregrinación con el Señor del Cerrito. México: Universidad Intercultural del Estado de México (uiem), Plaza y Valdés.

González Ortiz, Felipe. 2009. Multiculturalismo y metrópoli. Cultura politica en un fragmento urbano (antropología politica). México: Universidad Autónoma Metropolitana Unidad Iztapalapa (UAм-I).

González Ortiz, Felipe. 2012. Megalópoli y cultura. Del ritual indigena al performance urbano. México: Universidad Autónoma del Estado de México (uAEMex) y Porrúa Editores.

González Ortiz, Felipe. 2014. Carnavales metropolitanos. Acción ritual ante el crecimiento urbano. San Francisco Tlalcilalcalpan. México: Universidad Intercultural del Estado de MéxicoUIEM, Universidad Autónoma del Estado de México (uaEMex).
Kopytoff, Igor. 1991. "La biografía cultural de las cosas. La mercantilización como proceso". En La vida social de la cosas, editado por Arjun Appadurai. México: Consejo Nacional para la Cultura y las Artes (cNCA) y Grijalbo.

Lindón Villoria, Alicia. 1999. De la trama de la cotidianidad a los modos de vida urbanos. El Valle de Chalco. México: El Colegio de México, El Colegio Mexiquense.

Maffesoli, Michel. 1991. El tiempo de las tribus. El declive del individualismo en la sociedad de masas. Barcelona: Icaria editorial.

Malinowski, Bronislaw y Julio de la Fuente. 2011. La economía de un sistema de mercados en México. Un ensayo de etnografía contemporánea y cambio social en un valle mexicano,. México: Universidad Iberoamericana.

Marroquín, Alejandro. 1978. La ciudad mercado (Tlaxiaco). México: Instituto Nacional Indigenista (INI).

Paré, Luisa. 1988. El proletariado agrícola en México: ¿campesinos sin tierra o proletarios agrícolas? México: Siglo xxi.

Simmel, Georg. 1977. Filosofía del dinero. Madrid: Centro de estudios constitucionales.

Soustelle, Jacques. 1993. La familia otomípame en el México central. México: Fondo de Cultura Económica (FCE).

Van Gennep, Arnold. 1986. Los ritos de paso. Madrid: Taurus.

Zorita, Alonso de. 1942. Los Señores de la Nueva España. México: Imprenta Universitaria.

\section{PUBLICACIONES PERIÓDICAS}

Beals, Ralph. 1967. "The structure of the Oaxaca market system". Revista mexicana de estudios antropológicos, $\mathrm{n}$. 21: 333-342.

Galinier, Jacques. 1990b. "El depredador celeste. Notas acerca del sacrificio entre los mazahuas". Anales de antropología, n. 27.

Nivón Bolán, Eduardo. 2003. "Las contradicciones de la ciudad difusa". Alteridades, n. 26 : 15-35. 
Quiroz, Enriqueta. 2013. "Los mercados en la Colonia”. Arqueología mexicana 21, n. 122. Romero, Alejandro; Felipe Carlos Viesca y Maribel Hernández. 2011. "Formación del patrimonio gastronómico del valle de Toluca, México". Ciencia Ergo Sum 17, n. 3: 239-252.

Villela Flores, Samuel. 1999. "El análisis de los mercados campesinos". Tópicos de antropología económica 107-116. México: Instituto Nacional de Antropología e Historia (INAH) y Consejo Nacional para la Cultura y las Artes (conaculta).

Villela Flores, Samuel. 2013. "Mercados indígenas en México". Arqueología mexicana $21,122$.
OTROS

González Limón, Ana Belén. 1999. "Parque industrial Toluca 2000, sus características y su impacto sobre el territorio". Tesis de Licenciatura en Planeación Urbana y Regional. México: Universidad Autónoma del Estado de México (uaEMex).

Serrano Muciño, María Eugenia y María Violeta Serrano Muciño. 2012. Proceso de urbanización y cambio cultural en Santa María Totoltepec. Tesis de Licenciatura en Sociología de la Universidad Autónoma del Estado de México. México.

Fecha de ingreso: 06/01/2015 Fecha de aprobación: 12/05/2015 
